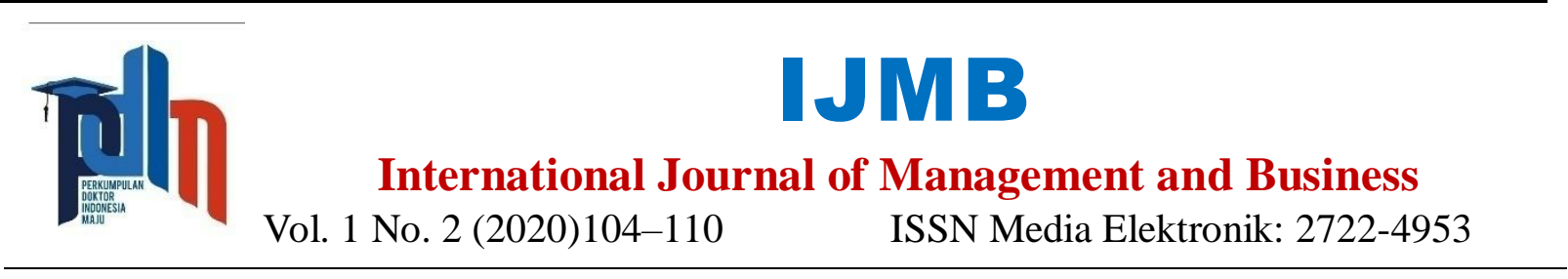

\title{
The Effect Of Experiential Marketing Toward Customer Loyalty (Empirical Study Of Fast Food Restaurants In Padang City)
}

\author{
Rasidah Nasrah $^{1}$, Agriqisthi ${ }^{2}$ \\ ${ }^{1}$ Muhammad YaminSolok University²Managanement Department, Andalas University \\ agriqisthi@eb.unand.ac.id
}

\begin{abstract}
Activity and limited of time to fulfill necessity caused people like instant things. Food sector is the main target for this pattern of act. Padang city is center of government, business and has several universities that bring people from other city to Padang. so that, food sector is targeted, especially young people who spend more time outside. The purpose of this study is to find out: the sense, feel, think, act, and relate affect toward customer loyalty of fast food restaurants in Padang city. This research used quantitative methods and uses SEM-PLS analysis to test research model. The observation unit in this study was 150 fast food restaurant customers in Padang City. In measuring variable used likert scale. The results found that the feel, and act have a significant effect toward customer loyalty of fast food restaurants in Padang City. While sense, think and relate do not have a significant effect on consumer loyalty toward fast food restaurants in Padang City.
\end{abstract}

Keyword: sense, feel, think, act, relate and customer loyalty

Abstrak

Aktivitas dan keterbatasan waktu untuk memenuhi kebutuhan menyebabkan orang menyukai hal-hal yang instan. Sektor pangan menjadi sasaran utama pola aksi ini. Kota Padang merupakan pusat pemerintahan, bisnis dan memiliki beberapa perguruan tinggi yang membawa orang-orang dari kota lain ke Padang. Sehingga sektor pangan menjadi sasaran, terutama kaum muda yang lebih banyak menghabiskan waktunya di luar. Tujuan dari penelitian ini adalah untuk mengetahui pengaruh sense, feel, think, act, dan relate terhadap loyalitas pelanggan restoran cepat saji di kota Padang. Penelitian ini menggunakan metode kuantitatif dan menggunakan analisis SEM-PLS untuk menguji model penelitian. Unit observasi dalam penelitian ini adalah 150 pelanggan restoran cepat saji di Kota Padang. Dalam mengukur variabel digunakan skala likert. Hasil penelitian menemukan bahwa feel, and act berpengaruh signifikan terhadap loyalitas pelanggan restoran cepat saji di Kota Padang. Sedangkan sense, think and relate tidak berpengaruh signifikan terhadap loyalitas konsumen terhadap restoran cepat saji di Kota Padang.

Kata kunci: sense, feel, think, act, relate, dan loyalitas pelanggan

(C) 2020JurnalIJMB

\section{Introduction}

People's Act changes depending on current trend, in resulting business actors must adapt. Moreover, nowadays uses of time is limited, so that people meet their needs immediately. The behavior pattern exhibited by community must be captured by business actors in order to superior in competition. The way that can be applied is to develop strategies or marketing programs so that can get more attention from the public. Rapid business development as happened in culinary sector to dominate the business field in various cities such as in Padang city.According to BPS [1] Padang city has potential in food sector, this can be seen from the growth that occurred from 2017 to 2018 which was quite significant in period in number 1,1551 in 2017 became 2,164 in 2018 . The figure places the food

DiterimaRedaksi :27-08-2020 | SelesaiRevisi : 31-10-2020 | Diterbitkan Online : 20-11-2020 
sector most dominating sector compared to the others sector, and absorb the most labor. Padang city is famous as many fast food restaurants that serve a variety of menus, both in traditional menus such as 'Nasi Padang' or other modern fast foods. According to BPS data [2] in 2016 there were 254 restaurants spread across all districts in Padang City.

This condition also shows that there is intense competition in culinary types / food businesses. Various types in marketing focus are carried out by businesses, but price factor is not a benchmark, because $93 \%$ make culinary industry as a place for recreation and get experience after making transactions [3]. Loyalty for example becomes an important part that must be realized by marketers, so that loyalty is used as an objective rather than a marketing strategy [4]. At the same time, one of factors that considered influential on customer loyalty is experiential marketing where customers are involved and gain experience from consuming goods and services [5] [6].Experience marketing is a new approach to providing information about brands and products. This is related to consumer experience and is very different from traditional marketing systems that focus on the functions and advantages of a product [7].Based on phenomenon that occurs, there is a sensation of experience after visiting a fast food restaurant in Padang city. The experience will form a loyalty if the experience gained is positive, but in other hand if negative will not form a loyalty. Positive experiences that can be built such as feeling of being in a cozy restaurant, or a good menu offered, besides a clean place, even the surrounding environment can also be influential.

\section{Marketing Experience}

Marketing Experience is considered to be effectively because in line with changing times and technology, marketers emphasize product differentiation to differentiate their products from competitors [7]. Experience marketing is a marketer's approach that involves the emotions and feelings of consumers by creating positive experiences that are not forgotten, so that consumers continue to consume certain products [8]. Customer involvement in this condition includes five things called strategic experiential modules (SEMs), which are modules that can be used to create various types of experiences for consumers, including [8]:

a. Senses, is a type of experience that arises to create an experience thorough five senses are: their eyes, ears, tongue, skin, and nose through products and services. b. Feel, aimed at the feelings and emotions of consumers with influencing aim experiences starting from the soft atmosphere day to make strong emotions of pleasure and pride

c. Think, is a type of experience that aims to create cognitive, problem solving that invites consumers to think more creatively

d. Act, is a type of experience that aims to influence behavior, lifestyle and interactions with consumers

e. Relate, is a type of experience that aims to influence consumers and combine all aspects of sense, feel, thik, act and focuses on creating positive perception in consumers eyes

\section{Consumer Loyalty}

Loyalty is defined as a commitment that is held strong to buy or subscribe to certain products or services in the future even though there are influences from situations and marketing efforts that have the potential to cause behavioral changes [9]. Loyalty can be measured based on; order of choice, proportion of purchases, preferences, commitment. While costumers said to have been loyal if they have repurchases, resilience and recommended to others [7].

\section{A. conceptual framework}

The framework for this research is as shown in Figure 1.

Figure 1: Conceptual Framework

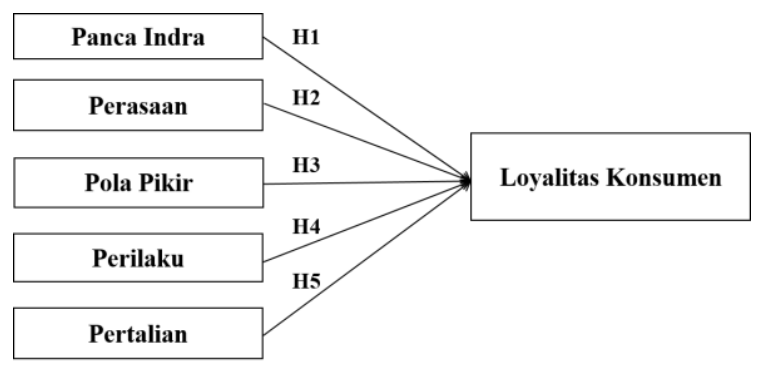

Data source: Related research

From Figure 1.shown the relationship of five senses, feelings, thought patterns, act and relate toward consumer loyalty. To examine this framework, the next steps determine by hypothesis, as follows:

H1: Allegedly sense has significant effect toward consumer loyalty to fast food restaurants in Padang city 
$\mathrm{H} 2$ : Allegedly feeling has significant effect toward consumer loyalty to fast food restaurants in Padang cityH3: Allegedly think has significant effect toward consumer loyalty to fast food restaurants in Padang cityH4: Allegedly act has significant effect toward consumer loyalty to fast food restaurants in Padang cityH5: Allegedly relate has significant effect toward consumer loyalty to fast food restaurants in Padang city

\section{RESEARCH METHODS}

\section{A. Types of research}

This research uses explanatory research that is research used to find out the influence in variable on particular situation [10]. This research used quantitative methods. The data collection distributed by questionnaires. This study used a cross-sectional time horizon. The observation unit in this study is fast food restaurant consumers in Padang city.

\section{B. Population, Samples and Sampling Techniques}

The technique used is a non-probability sampling technique with type used is accidental sampling, is a technique of determining samples based on chance, is anyone who accidentally met with the researcher can be used as a sample [10]. The sample size in this study was 150 respondents.

\section{Definition of Variable Operations}

In this study operational limitations used are as follows [7]:

1. Exogenous variables, namely the five senses, feel, think, act, and relate.

2. Endogenous variables in this study are consumer loyalty

\section{Data Processing Techniques}

This study used data analysis method SmartPLS 2 software that is run on computer media. PLS is an analysis of variance-based structural equations that can simultaneously test measurement models as well as structural model testing [11].

In accordance with the hypotheses that have been formulated, then in this study inferential statistical data analysis is measured used SmartPLS 2.0 software ranging from measurement models (outer models), structure models (inner models) and hypothesis testing [11].PLS uses a three-stage iteration process and each iteration stage produces an estimate. The first stage, produces a weight estimate that is used to create a score of latent variables. The second step produces estimates for the inner model and outer model and reflects the path estimate (path estimate) that connects the latent variable and between the latent variable and its indicator (loading). The third stage produces estimated means and location parameters (regression constant values) for indicators and latent variables [12].

\section{Outer Model}

The construct validity test in PLS is carried out through convergent validity, discriminant validity and average variance extracted (AVE) tests. Reliability test is used to measure the consistency of measuring instruments in measuring concepts or can also be used to measure the consistency of respondents in answering instruments. Instruments are said to be reliable if a person's answer to a statement is consistent or stable over time. Reliability test in PLS can use composite reliability and cronbach's alpha methods [12].

\section{Inner model}

Inner models (inner relations, structural models, and substantive theory) describe the relationship between latent variables based on substantive theory. Structural models are evaluated using R-square for dependent constructs, StoneGeisser Q-square tests for predictive relevance, and $\mathrm{t}$ tests as well as the significance of the structural path parameter coefficients [12].

\section{Hypothesis test}

The significance measure of hypothesis support can be used to compare t-table and t-statistic values. The hypothesis is supported or accepted if the $\mathrm{t}$-statistic is higher than the t-table value or it can also compare the $\mathrm{p}$-value with the $\alpha$ value used. The $\mathrm{t}-$ table value for the one-tailed hypothesis with 95 percent confidence level $(\alpha=0,05)$ is 1,96 . Supporting the hypothesis in the study occurs when the t-statistic value $>1,96$ or $p$-value $<\alpha=0,05$. PLS analysis used in this study was conducted using the SmartPLS 2 program which was run on computer media [12] [11].

\section{RESULTS AND DISCUSSION}

As explained in the research method that to analyze data used 3 stages, namely the outer model, inner model and hypothesis testing. 


\section{A. Outer Model}

\section{Initial Outer Loading}

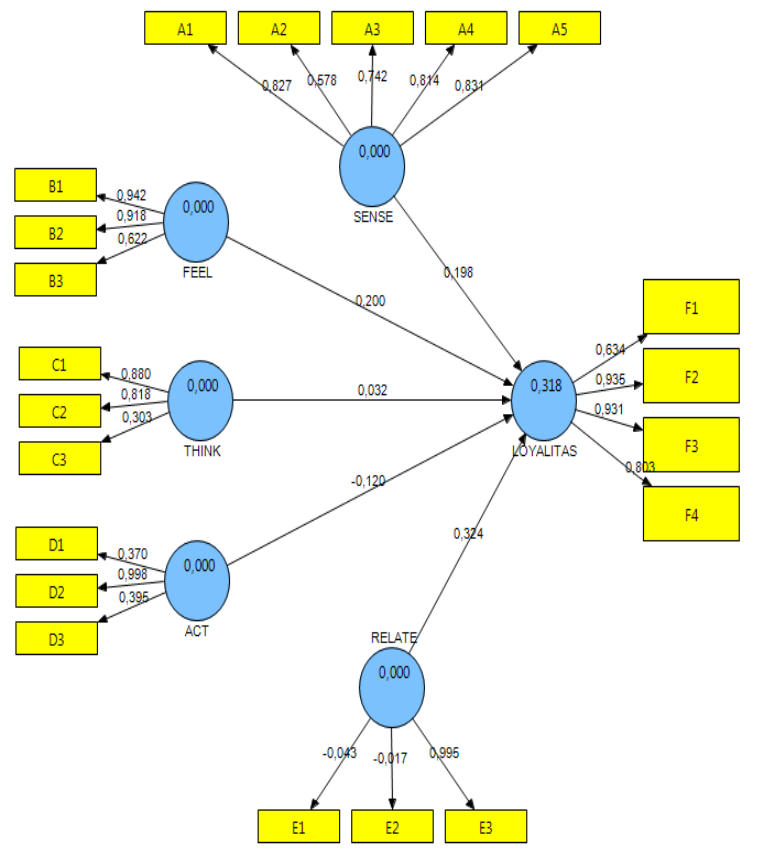

Figure 2: Initial Construction Image

Data source: Primary data processed

First, in using Smart-PLS software must built a construct as shown in Figure 2. The construct is built with aim of making a research framework that enhances the relationship of exogenous variables to endogenous. From Table 1. Showing the results of data processing; There are several research indicators that have convergent validity values below 0.5 . These indicators will be issued / dropped and then processed if the data (running) again to produce convergent validity values above 0.5 .

Table 1: Initial Outer Loading Results

\begin{tabular}{lll}
\hline Indicator & Loading Factor & $\begin{array}{l}\text { Test } \\
\text { Information }\end{array}$ \\
\hline Sense (X1) & 0,826944 & Validity \\
X1.1 & 0,578171 & Valid \\
X1.2 & 0,741596 & Valid \\
X1.3 & 0,813758 & Valid \\
X1.4 & 0,831103 & Valid \\
X1.5 & & \\
Feel (X2) & 0,942112 & Valid \\
X2.1 & 0,917836 & Valid \\
X2.2 & 0,622267 & Valid \\
X2.3 & & \\
Think (X3) & 0,879523 & Valid \\
X3.1 & 0,818413 & Valid
\end{tabular}

\begin{tabular}{lcl} 
X3.3 & $\underline{\mathbf{0 , 3 0 3 4 2 8}}$ & Invalid \\
Act (X4) & $\underline{\mathbf{0 , 3 6 9 9 7 1}}$ & Invalid \\
X4.1 & $\underline{0,998071}$ & Valid \\
X4.2 & $\underline{\mathbf{0 , 3 9 5 3 2 1}}$ & Invalid \\
X4.3 & & \\
Relate (X5) & $\underline{\mathbf{- 0 , 0 4 3 0 1 2}}$ & Invalid \\
X5.1 & $\underline{\mathbf{0 , 0 1 7 0 0 9}}$ & Invalid \\
X5.2 & 0,994603 & Valid \\
X5.3 & \\
Costumers loyalty(Y) & \\
Y1.1 & 0,634289 & Valid \\
Y1.2 & 0,935082 & Valid \\
Y1.3 & 0,931048 & Valid \\
Y1.4 & 0,802957 & Valid \\
\hline \multicolumn{4}{c}{ Data source: Primary data processed }
\end{tabular}

Furthermore, Figure 3 becomes final construct after eliminating several indicators that do not meet the requirements.

Figure 3: Final Construction Image

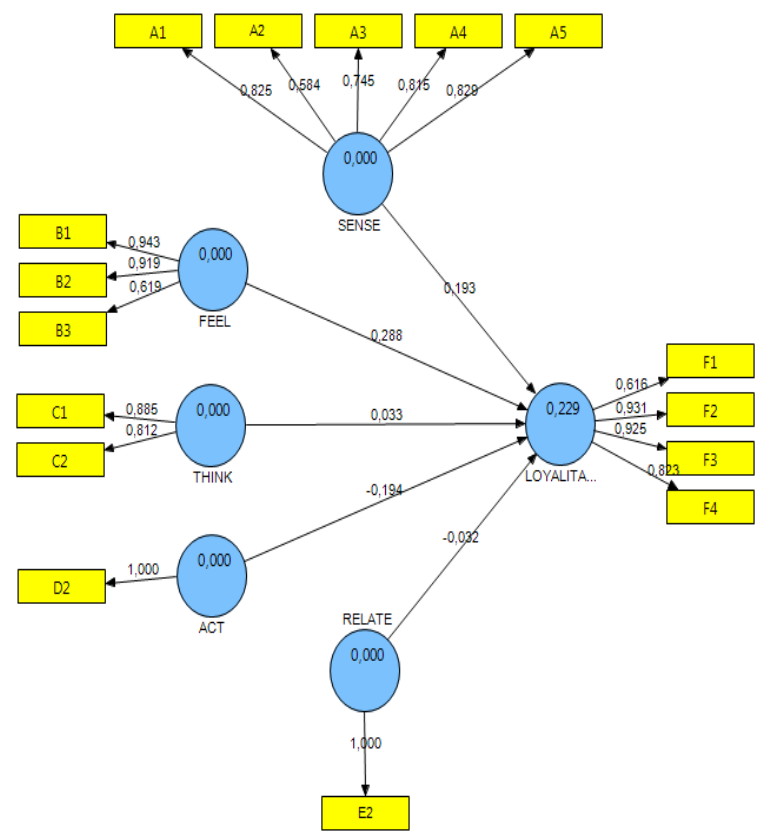

Data source: Primary data processed

Table 2: Final Outer Results

\begin{tabular}{lll}
\hline Indicator & Loading Factor & $\begin{array}{l}\text { Test } \\
\text { Information }\end{array}$ \\
\hline Sense (X1) & 0,824959 & \\
X1.1 & 0,583513 & Valid \\
X1.2 & 0,744597 & Valid \\
X1.3 & 0,815090 & Valid \\
X1.4 & 0,829383 & Valid \\
X1.5 & & Valid \\
Feel (X2) & 0,942806 & Valid \\
X2.1 & 0,918942 & Valid \\
X2.2 & 0,619451 & Valid \\
X2.3 & & \\
Think(X3) & 0,884973 & Valid \\
X3.1 & 0,811996 & Valid \\
X3.2 & & \\
Act (X4) & 1,000000 & Valid \\
X4.2 &
\end{tabular}




\begin{tabular}{|c|c|c|}
\hline \multicolumn{3}{|c|}{ Relate (X5) } \\
\hline $\mathrm{X} 5.3$ & 1,000000 & Valid \\
\hline \multicolumn{3}{|c|}{ Costumers loyalty $(\mathrm{Y})$} \\
\hline Y1.1 & 0,616288 & Valid \\
\hline Y1.2 & 0,931472 & Valid \\
\hline Y1.3 & 0,925048 & Valid \\
\hline Y1.4 & 0,822952 & Valid \\
\hline
\end{tabular}

Data source: Primary data processed

Table 2 shows that all indicators have convergent validity values above 0.5 and have been declared valid.

Table 3: Average Variance Extract

\begin{tabular}{ll}
\hline Variable & AVE \\
\hline Sense & 0,585543 \\
Feel & 0,705685 \\
Think & 0,721257 \\
Act & 1,000000 \\
Relate & 1,000000 \\
Costumers loyalty & 0,695104 \\
\hline
\end{tabular}

Data source: Primary data processedThe value of each variable shown in table 3 . has a value above 0.5 so that it can be conclude that each indicator that measures a variable already has a good validity value.

\begin{tabular}{lc}
\multicolumn{2}{c}{ Table 4: Composite Reliability } \\
\hline Variable & Composite Reliability \\
\hline Sense & 0,874358 \\
Feel & 0,874569 \\
Think & 0,837808 \\
Act & 1,000000 \\
Relate & 1,000000 \\
Costumers loyalty & 0,899054 \\
\hline Data source: Primary data processed
\end{tabular}

The final result after applied estimation, the reliability test shows that the final result has fulfilled the requirements where the composite reliability value is more than 0.7 .

\section{B. Inner model}

R-square value of 0.229390 on consumer loyalty, means that the five senses, feelings, think, Act, and relate can explain the variable of consumer loyalty by $22.94 \%$. while the other $77.06 \%$ is influenced by other factors not addressed in this study.

Table 5: R-Square

\begin{tabular}{ll}
\hline Variable & R-Square \\
\hline Sense & \\
Feel & \\
Think & \\
Act & \\
RElate & \\
Costumers loyalty & 0,229390 \\
\hline
\end{tabular}

Data source: Primary data processedMore higher the r-square value, so that more greater the exogenous ability variables to be able to explain endogenous variables.

\section{Hypothesis test}

After testing hypothesis so that statistical $t$ value can be seen in table 6 . The $\alpha$ used is $5 \%$ so it has t table 1.97591. Next to determine whether there is a significant influence by comparing the value of $t$ statistics with t tables. Significant effect if $t$ statistic $>$ $\mathrm{t}$ table, whereas if $\mathrm{t}$ statistic <from $\mathrm{t}$ table then declared no significant effect. These results will be representative of the primary data obtained. The results are in accordance with conditions when collecting data.

Table 6: Hypothesis Testing Results

\begin{tabular}{|c|c|c|}
\hline Relate & $\begin{array}{l}\text { T } \quad \text { Statistics } \\
(|\mathrm{O} / \mathrm{STERR}|)\end{array}$ & Sig. Level \\
\hline SENSE & 1,747278 & Insignificant \\
\hline \multicolumn{3}{|l|}{ COSTUMERS } \\
\hline \multicolumn{3}{|l|}{ LOYALTY } \\
\hline FEEL-> & 2,558143 & Significant \\
\hline \multicolumn{3}{|l|}{ COSTUMERS } \\
\hline \multicolumn{3}{|l|}{ LOYALTY } \\
\hline THINK & 0,297064 & Insignificant \\
\hline \multicolumn{3}{|l|}{ COSTUMERS } \\
\hline \multicolumn{3}{|l|}{ LOYALTY } \\
\hline ACT-> COSTUMERS & 2,004160 & Significant \\
\hline \multicolumn{3}{|l|}{ LOYALTY } \\
\hline RELATE-> & 0,358690 & Insignificant \\
\hline \multicolumn{3}{|l|}{ COSTUMERS } \\
\hline LOYALTY & & \\
\hline
\end{tabular}

Data source: Primary data processedThere are two variables that have a significant influence on consumer loyalty, namely feelings and behavior because they have a statistical $t$ value $>t$ table. While the five senses, mindset and relationship variables do not significantly influence consumer loyalty.

\section{Discussion}

The Influence of Five Senses toward Consumer Loyalty

The five senses include (sight, smell, hearing, taste, and touch) do not have a significant effect on loyalty. This is not in line with research conducted by [4]. This is caused by differences in the demographics of respondents studied, and conditions when collecting data in field. In Padang city consumer behavior is not too concerned about the five senses in forming loyalty at fast food restaurants. This result is in line with research conducted by [5] which states that experience marketing does not directly affect loyalty, but can form satisfaction first.

The effects of Feelings toward Consumer Loyalty Feelings can be measured through mood, comfort, and emotions. Feelings have a significant effect on consumer loyalty. The results of this study are in line with research conducted by [4]. . These results indicate that the higher the experience that comes from feelings, moods and emotions, the higher level of customer loyalty to fast food restaurants in Padang 
city. It not only offers the benefits of a product but also touches the feelings that arise in consumers mind when consuming a product and makes it an unforgettable experience in consumers mind.

The Effect of think toward Consumer LoyaltyThink does not have a significant influence on consumer loyalty, while mindset can be measured through admiration, stories from other people, and encouragement. This is because consumers decide to visit fast food restaurants in Padang city without any encouragement, admiration or stories from others. However, these results are not in linewith research by who mentioned a significant influence by mindset[4]However, research conducted by states that there is no significant effect[5].

Effect of act toward Consumer Loyalty

Act can significantly influence consumers loyalty on fast food restaurants in Padang city. This is because shopping at fast food restaurants in Padang city is in accordance with consumers life style, good service, or interactive. These results are consistent with research conducted by [4]. .

\section{Effect of Relate toeard Consumer Loyalty}

Relate does not have a significant effect on forming consumer loyalty on fast food restaurants in Padang. This is because consumers feel that management is not good or consumers also relate it to other things such as the behavior of managers or restaurant employees. This is actually not in line with research conducted

byPengaruhPertalianTerhadapLoyalitasKonsumen[4]

\section{CONCLUSION}

A. Conclusion

Based on SEM (Structural Equational Modeling) test results using SmartPLS, it can be concluded that:

1. The five sense has no effect toward consumers loyalty on fast food restaurants in Padang city. The results of this study indicate that the higher dimensions of the five senses will not necessarily affect toward consumer loyalty.

2. Feel affect toward consumers loyalty on fast food restaurants in Padang city. The results of this study indicate that the higher or increased feeling dimension, the consumer's loyalty on fast food restaurants in Padang city will also increase.

3. Think does not affect toward consumer loyalty. The results of this study indicate that the increase or decrease in the dimensions of mindset does not necessarily affect toward consumer loyalty.
4. Act affects toward consumers loyalty on fast food restaurants in Padang city. The results of this study indicate that the higher or increased the dimensions of behavior, Janiah's consumer loyalty will also increase.

5. Relate does not affect toward consumers loyalty on fast food restaurants in Padang city. Maybe this can happen because management of fast food restaurants is still not good, the lack of interaction or management relations with consumers and the decline in the prestige of fast food restaurants causes the relate dimension has no effect on customer loyalty

\section{B. Implications of Research Results}

Found several useful implications for manager of fast food restaurants in Padang city to optimizing the marketing experience, where feelings and act influence to increase consumer loyalty. Implications for the management of fast food restaurants to pay more attention to experience from the dimensions of feelings and act because both of dimensions have a strong relationship and affect toward consumer loyalty.

\section{Suggestion}

For Fast Food Restaurant Operators in Padang City

Managers can implement marketing strategies through experience marketing strategies with dimensions of feelings and behavior. The suggestions addressed to managers are:

\section{Feel}

a. Managers must create a sense of pleasure for consumers such as holding entertainment events.

b. Providing polite and friendly service will provide comfort for consumers.

c. Provide merchandise that attracts consumers' attention.

Act

a. Managers to be able to maintain the cleanliness and security of restaurants.

b. Providing facilities and services that fit the needs of consumers. This is very useful for the convenience of consumers while on location.

c. Increased relationships and interactions between employees and consumers.

\section{For Future Research}

a. In future studies, researchers are expected to get a more diverse sample such as samples of 
consumers from outside the Padang city where will get different information.

b. It is expected that future research will get information from the government and other related department, it will get information that is not one-way from consumers.

\section{DaftarRujukan}

[1] B. Kota Padang Dalam Angka, "Kota Padang Dalam Angka 2018," 2018.

[2] B. Kota Padang Dalam Angka, "Kota Padang Dalam Angka 2019,", 2019.

[3] O. A. Noegroho, Suharyono, And S. Kumadji, "Pengaruh Experiential Marketing Dan Brand Trust Terhadap Kepuasan Pelanggan Dan Loyalitas Pelanggan (Survei Pada Pelanggan Kfc Cabang Kawi Malang)," Vol. 6, No. 2, Pp. 1-7, 2013.

[4] A. Bisnarti, "Pengaruh Experiential Marketing Terhadap Loyalitas Pelanggan," Vol. 1, No. 1, Pp. 49-57, 2015.

[5] R. Chao, "The Impact Of Experimental Marketing On
Customer Loyalty For Fitness Clubs: Using Brand Image And Satisfaction As The Mediating Variables," Vol. 10, No. 2, Pp. 52-60, 2015.

[6] Y. A. Putri And S. E. T. Astuti, "Analisa Pengaruh Experiential Marketing Terhadap Loyalitas Pelanggan Hotel “X' Semarang," Vol. 12, No. 2, Pp. 191-199, 2010.

[7] A. Christian And D. Dharmayanti, "Pengaruh Experiential Marketing Terhadap Customer Satisfaction Dan Customer Loyalty The Light Cup Di Surabaya Town Square," Vol. 1, No. 2, Pp. 1-13, 2013.

[8] B. Schmitt, "Experiential Marketing: A New Framework For Design And Communications," Vol. 10, Pp. 19-27, 2015.

[9] P. Kotler And K. L. Keller, Manajemen Pemasaran Jilid 1, Edisi Ketiga Belas, Terjemahan Bob Sabran. 2009.

[10] U. Sekaran, Research Methods For Business Metedologi Penelitian Untuk Bisnis. 2015.

[11] I. Ghozali, Aplikasi Analisi Multivariate Dengan Menggunakan Spss. 2014.

[12] J. F. Hair, W. C. Black, B. J. Babin, And R. E. Anderson, Multivariate Data Analysis 7ed. 2010. 